\title{
Pogranicze w politologii
}

Radosław Zenderowski ${ }^{1}$

Link do artykułu:

http://pogranicze.uni.opole.pl/biblioteka/docs/nr1/zenderowski_nr1.pd

Standard cytowania (APA):

Zenderowski, R. (2013). Pogranicze w politologii. Pogranicze. Polish Borderlands Studies, nr 1, s. 81 .

Uważam, że politologowie, ale także specjaliści z zakresu stosunków międzynarodowych czy geopolityki w „naturalny” sposób skoncentrowani są na pojęciu granicy, zupełnie niemal pomijając w swoich analizach zagadnienie pogranicza. Wielu politologów uznaje, że powinno być ono przedmiotem analiz prowadzonych na gruncie socjologii, etnologii, antropologii kulturowej. Nie jest to, w moim przekonaniu podejście słuszne.

Kategoria pogranicza, która pojawia się choćby w studiach europeistycznych (w znacznej mierze opierających się na metodologii badań politologicznych), znajduje zastosowanie w analizach dokonujących się w Europie (w mniejszym stopniu poza Europą) procesach politycznej i społecznej integracji. Fenomen pogranicza rozumianego w kategoriach przestrzeni peryferyjnej (najczęściej względem politycznego centrum), w warunkach zmieniającej się funkcji granic, jest godzien pogłębionych studiów politologicznych, albowiem podlega on dynamicznym przemianom, mającym także swój wymiar polityczny.

$\mathrm{Na}$ przestrzeni kilkunastu ostatnich lat, zwłaszcza w okresie po 2004 roku widzimy na własnym ,podwórku”, jak peryferyjne z obu stron granicy obszary pograniczne podlegają procesom społecznej, gospodarczej i kulturowej integracji lub reintegracji (w przypadku regionów historycznych podzielonych $\mathrm{w} X X$ wieku granicą państwową). Wzmocnieniu ulega tożsamość regionalna, poczucie przynależności do wielokulturowego regionu, będącego „małą ojczyzną" dla ludzi władających na co dzień różnymi językami, ale odnajdujących w procesie (re)integracji wspólne wartości, co często zdumiewa ich samych. Osobiście obserwuję ów proces w miejscu zamieszkania - na Śląsku Cieszyńskim. Regiony transgraniczne, które jeszcze nie tak dawno składały się z dwóch lub więcej „szczelnie” odseparowanych od siebie pograniczy jako swoistych stref buforowych - stają się w dobie „Europy regionów" podmiotami nie tylko lokalnej, ale w pewnym stopniu - także międzynarodowej polityki.

Innymi słowy, to co powinno interesować politologa, to proces „deperyferyzacji” pogranicza. Z „martwej” strefy buforowej utrzymywanej nierzadko na poziomie zapóźnienia cywilizacyjnego, pogranicza stają się strefą intensywnych procesów wymiany społecznej, gospodarczej i kulturowej, nierzadko żywiołowej, nieinicjowanej odgórnie i niekontrolowanej administracyjnie integracji.

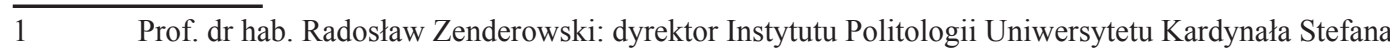
Wyszyńskiego w Warszawie. 